\title{
De WHOA, pensioen en de rechten van werknemers
}

\author{
Mr. R.J. van Galen, prof. mr. T.H.D. Struycken en \\ mr. S.B.A. Heumakers*
}

\section{Inleiding}

Pensioenfondsen vormen een categorie schuldeisers waarmee men zich niet goed raad weet sinds de inwerkingtreding van de Wet homologatie onderhands akkoord (WHOA) op 1 januari 2021, als nieuwe tweede afdeling van titel IV Fw. Daarin is bepaald, in art. 369 lid $4 \mathrm{Fw}$, dat deze regeling voor herstructurering van schulden niet van toepassing is 'op rechten van werknemers in dienst van de schuldenaar die voortvloeien uit arbeidsovereenkomsten in de zin van artikel 610 van Boek 7 van het Burgerlijk Wetboek'.

Rechten van werknemers omvatten in ieder geval het recht van een werknemer op betaling van loon, vakantiegeld en andere vergoedingen. Het begrip omvat hoogstwaarschijnlijk ook rechten van oud-werknemers. Bijvoorbeeld het recht van een gewezen werknemer op een transitievergoeding valt onder de reikwijdte van de uitzondering in art. 369 lid $4 \mathrm{Fw}$ en kan dus niet door middel van een WHOA-akkoord worden gekort. Het recht van een gewezen werknemer op een transitievergoeding bestaat immers op grond van art. 7:673 $\mathrm{BW}$ als er een arbeidsovereenkomst bestond die is beëindigd op initiatief van de werkgever en verder voldoet aan de voorwaarden van art. 7:673 BW. Het recht bestaat daarom dus vanwege het bestaan van de arbeidsovereenkomst en vloeit daarmee voort uit de arbeidsovereenkomst, al is daar geen toelichting over verschaft in de parlementaire geschiedenis bij de WHOA. Ook in de beschikbare literatuur wordt het standpunt ingenomen dat een transitievergoeding volledig zal moeten worden betaald, gezien art. 369 lid 4 Fw. ${ }^{1}$

De grote vraag nu is of óók de vordering van een pensioenfonds op een onderneming valt binnen de uitsluiting van de toepasselijkheid van de WHOA-regeling op de voet van art. 369 lid $4 \mathrm{Fw}$. In de praktijk gaat het dan vooral om achterstallige pensioenpremies, die door de werkgever niet zijn afgedragen. Zouden ook (reeds ontstane) vorderingen van pensioenfondsen onder de uitsluiting vallen, dan zouden deze vorderingen niet kunnen worden gekort door homologatie van

* Mr. R.J. van Galen is advocaat bij NautaDutilh te Amsterdam. Prof. mr. T.H.D. Struycken is advocaat bij NautaDutilh te Amsterdam en hoogleraar te Utrecht. Mr. S.B.A. Heumakers is advocaat bij NautaDutilh te Amsterdam.

1 K.C. Mensink, M.M. Dellebeke \& P.C. van Prooijen, Liquidatieakkoorden onder de WHOA, TvCu 2020, afl. 4, p. 99 (l.k.). een onderhands akkoord en zouden pensioenfondsen daarmee geen reden hebben om in te stemmen met enige vermindering van door een onderneming verschuldigde achterstallige pensioenpremiebetalingen. ${ }^{2}$ In deze bijdrage zullen we uiteenzetten waarom wij van mening zijn, mede in het licht van Europese regelgeving, dat de vorderingen van een pensioenfonds niet onder de reikwijdte van de uitzondering in art. 369 lid 4 Fw vallen en dus wel kunnen worden meegenomen in een WHOA-akkoord.

De in paragraaf 2 te behandelen vraag of vorderingen van pensioenfondsen kunnen worden meegenomen in een WHOA-akkoord staat inmiddels centraal in diverse procedures. ${ }^{3}$ In één daarvan is een prejudiciële vraag aan de Hoge Raad gesteld. ${ }^{4} \mathrm{Bij}$ het finaliseren van deze bijdrage verscheen de conclusie van Advocaat-Generaal De Bock in deze procedure. Zij concludeert dat vorderingen van pensioenfondsen binnen de uitsluiting in art. 369 lid $4 \mathrm{Fw}$ vallen.

De beperking van het toepassingsbereik van de WHOA-procedure in art. 369 lid $4 \mathrm{Fw}$ doet ook andere vragen rijzen met betrekking tot rechten van werknemers. Van belang is of een afkoelingsperiode ook kan zien op de rechten van pensioenfondsen, welke vraag in paragraaf 3 aan de orde komt.

\section{De vordering van een pensioenfonds}

Voor de beoordeling of een vordering tot betaling van achterstallige pensioenpremies buiten de reikwijdte van de WHOA-procedure voor de herstructurering van schulden valt, kunnen verschillende invalshoeken worden gekozen. Eerst besteden wij in paragraaf 2.1 aandacht aan het wettelijk kader van een WHOA-akkoord. Dan komt in paragraaf 2.2 een arrest van de Hoge Raad uit 2015 aan de orde, dat de rechten van een pensioenfonds in geval van een overgang van onderneming reliëf heeft gegeven. Of het arrest ook maatgevend moet zijn in het kader van een WHOA is ongewis en discuta-

2 Het gaat om reeds verschuldigd geworden pensioenpremies. Toekomstige premiebetalingen kunnen waarschijnlijk niet worden gekort. Overigens kan een WHOA-akkoord geen wijzigingen afdwingen in lopende contracten; wel kan een contract worden beëindigd indien de wederpartij niet instemt met voorgestelde wijzigingen.

3 Rb. Amsterdam 23 maart 2021, ECLI:NL:RBAMS:2021:1874.

4 Rb. Amsterdam 23 augustus 2021, ECLI:NL:RBAMS:2021:4475, JOR 2021/304 m.nt. J.L.M. van Groenewegen, PJ 2021/133 m.nt. E. Lutjens. 


\section{Maandblad \\ Vermogensrecht}

bel, zoals te bespreken in paragraaf 2.3. Rechtspolitiek is het uiteindelijk een verdelingsvraagstuk, zo wordt uiteengezet in paragraaf 2.4. Vervolgens komt in paragraaf 2.5 de Europese dimensie aan bod. Ten slotte bespreken wij de conclusie van de A-G in paragraaf 2.6.

\subsection{Het kader van een WHOA-procedure}

Een WHOA-akkoord met schuldeisers behelst blijkens art. 370 lid $1 \mathrm{Fw}$ 'een wijziging van hun rechten'. Als de vordering van het pensioenfonds op een onderneming tot betaling van (achterstallige) pensioenpremies wordt aangemerkt als 'een recht van de werknemer' en deze vordering daarmee binnen de reikwijdte van de uitsluiting van art. 369 lid 4 Fw valt, blijft het pensioenfonds geheel buiten het WHOA-akkoord. Als de vordering van het pensioenfonds buiten de reikwijdte van de uitsluiting van art. 369 lid $4 \mathrm{Fw}$ valt, is denkbaar dat de achterstallige premieschuld wordt gekort, zodat niet langer het totale bedrag betaalbaar is, maar slechts het (lagere) bedrag dat onder het WHOA-akkoord betaalbaar wordt. Daarbij gelden dan wel de randvoorwaarden voor een WHOA-akkoord, zoals (1) het uitgangspunt van art. 384 lid 3 Fw dat het pensioenfonds tenminste moet krijgen wat het pensioenfonds in geval van faillissement zou krijgen, en (2) het uitgangspunt van art. 384 lid 4 sub b Fw dat bij de allocatie van de reorganisatiewaarde (de geschatte waarde van de onderneming na de herstructurering van haar schulden op basis van het WHOA-akkoord) niet mag worden afgeweken van de rangorde van de rechten van de verschillende schuldeisersgroepen volgens de wet (de absolute priority rule).

In de literatuur worden verschillende standpunten ingenomen met betrekking tot de vraag of het vorderingsrecht van een pensioenfonds valt onder de reikwijdte van de uitsluiting in art. 369 lid 4 Fw. Visscher ${ }^{5}$ schrijft dat het hem aannemelijk lijkt dat de vorderingen van een bedrijfstakpensioenfonds die voortvloeien uit een dienstbetrekking wel onderdeel kunnen zijn van een WHOA-akkoord (en dus buiten de uitsluiting vallen), op de gronden (a) dat de wetgever blijkens de toelichting volgens hem niet heeft beoogd deze rechten uit te sluiten van de WHOA, en (b) dat de WHOA veel minder effectief zou zijn als pensioenrechten niet kunnen worden gekort, doordat een bedrijfstakpensioenfonds door middel van een dwangbevel executoriaal beslag zou kunnen leggen, waarbij hij kennelijk van mening is dat ook de afkoelingsperiode niet van toepassing zou zijn als pensioenrechten onder de uitsluiting in art. 369 lid 4 Fw zouden vallen. Van den Sigtenhorst ${ }^{6}$ stelt dat 'aannemelijk is dat naast loon bijvoorbeeld ook pensioenrechten' binnen de reikwijdte van de uitsluiting in lid 4 vallen; inmiddels vindt hij ook verdedigbaar dat vorderingen van een

5 M.H. Visscher, Van bange bestuurders naar creatieve bestuurders als het om pensioenschulden gaat?, TvOB 2020, afl. 6, par. 4.1.

6 Van den Sigtenhorst, in: T\&C Insolventierecht 2020, art. 369, aant. 5, p. 825 . bedrijfspensioenfonds buiten de uitzondering vallen. ${ }^{7}$ Van der Pijl ${ }^{8}$ stelt dat onder 'rechten' in lid 4 vallen:

'alle aanspraken uit hoofde van de arbeidsverhouding, dus naast loon ook (bijvoorbeeld) vakantiedagen, variabele beloning, pensioenbijdragen en loon in natura of ter beschikking gestelde bedrijfsmiddelen als telefoon, laptop en leaseauto. Eventuele ontslagvergoedingen, of deze nu voortvloeien uit de wet (de transitievergoeding), uit een rechterlijke uitspraak (zoals de billijke vergoeding) of uit een collectieve regeling (sociaal plan) of individuele afspraak (vaststellingsovereenkomst), blijven naar mijn mening buiten schot.'

Wat de duiding van art. 369 lid 4 Fw betreft, in het bijzonder het element 'rechten van werknemers', is een vraag of dit alleen om vorderingsrechten tot betaling van een geldsom aan een werknemer gaat (de enge interpretatie), of ook om andersoortige rechten (de ruime interpretatie), zoals het recht dat aan een betrokken derde (zoals een pensioenfonds) een betaling wordt gedaan. Volgens de memorie van toelichting kan een akkoord geen wijzigingen aanbrengen in de rechten van werknemers op basis van de arbeidsovereenkomst: 'De rechtspositie van werknemers kan niet worden gewijzigd door het akkoord en blijft dus geborgd." Deze formulering kan duiden op een ruime interpretatie van het begrip 'rechten van werknemers', maar het antwoord is niet in detail uitgewerkt.

\subsection{Het arrest uit 2015}

Voor beantwoording van de vraag of een pensioenfonds vorderingen heeft die door middel van een WHOA-akkoord kunnen worden gekort, in het licht van art. 369 lid $4 \mathrm{Fw}$, is een arrest uit 2015 van belang. ${ }^{10}$ Dat ging om een geschil tussen enerzijds de Stichting Bedrijfstakpensioenfonds voor het Schoonmaak- en Glazenwassersbedrijf en anderzijds een onderneming genaamd GOM Schoonhouden B.V. Een derde, VBG, had haar onderneming verkocht aan GOM door middel van een activa-passivatransactie. VBG en GOM namen beide verplicht deel aan het bedrijfstakpensioenfonds. Nadat VBG failliet was verklaard (na het moment van overgang van onderneming), sprak het bedrijfstakpensioenfonds GOM aan voor de door VBG niet-betaalde pensioenpremies. GOM betrok twee stellingen: ten eerste de stelling dat de niet-betaalde pensioenpremies niet onder 'de rechten en verplichtingen die op dat tijdstip voor de werkgever in die onderneming voortvloei-

$7 \quad$ R. van den Sigtenhorst \& P. Jahan, Prejudiciële vragen over de reikwijdte van de WHOA: vorderingen van bedrijfspensioenfondsen uitgezonderd?, TvI 2021/49.

8 J. van der Pijl, De positie van de werknemer en de ondernemingsraad onder de WHOA, in: L.J.J. Kerstens, B. Rikkert, M.A. Broeders \& R.F. Feenstra (red.), Wet Homologatie Onderhands Akkoord (INSOLAD Jaarboek 2021), Deventer: Wolters Kluwer 2021, par. 2.1.1.

9 Parlementaire geschiedenis van de WHOA, Kamerstukken II 2018/19, 35249 , nr. 3, p. 9.

10 HR 14 oktober 2016, ECLI:NL:HR:2016:2375, JOR 2017/57 m.nt. Loesberg, Ondernemingsrecht 2017/19 m.nt. Verburg, PJ 2016/156 m.nt. Huijg. 


\section{Maandblad Vermogensrecht}

en uit een arbeidsovereenkomst tussen hem en een daar werkzame werknemer' vallen, zodat de verplichting om de nog niet betaalde pensioenpremies alsnog te betalen niet op grond van art. 7:663 BW op GOM als verkrijger was overgegaan. En ten tweede de stelling dat het bedrijfstakpensioenfonds geen (zelfstandig) vorderingsrecht heeft, omdat art. 7:663 BW alleen aan de werknemer een vordering geeft.

De Hoge Raad oordeelde dat een bedrijfstakpensioenfonds wel een eigen recht heeft jegens de verkrijgende werkgever ter zake van de inning van achterstallige pensioenpremies:

'3.10 Verplichtingen die voortvloeien uit een arbeidsovereenkomst ter zake van pensioen hebben als bijzonderheid dat daarbij in de regel sprake is van een driehoeksverhouding tussen de werknemer, de werkgever en een pensioenuitvoerder als bedoeld in art. 23 lid 1 in verbinding met art. $1 \mathrm{Pw}$. De werkgever is uit hoofde van de pensioenovereenkomst (of daarmee gelijk te stellen rechtsbetrekking in geval van verplichte deelneming op grond van de Wet Bpf 2000, zie hiervoor in 3.5) jegens de werknemer verplicht tot premiebetaling aan de pensioenuitvoerder. De pensioenuitvoerder heeft daarnaast een eigen recht jegens de werkgever op betaling van de premie. In (de wetsgeschiedenis van) de art. 7:663 en 7:664 BW wordt niet onderscheiden tussen de verplichting van de werkgever tot betaling van pensioenpremie in zijn verhouding tot de werknemer en die in zijn verhouding tot de pensioenuitvoerder. Wel blijkt uit de wetsgeschiedenis (...) dat de wetgever heeft beoogd het mogelijk te maken dat de verkrijgende werkgever wordt aangesproken voor een achterstand in premiebetaling van de overdragende werkgever, zij het dat de wetgever de kans daarop niet groot heeft geacht in verband met de gelijktijdige afschaffing van de mogelijkheid tot zogeheten uitstelfinanciering. Daarbij is opgemerkt dat de verkrijger met dit aspect bij de onderhandelingen over de overgang van een onderneming rekening dient te houden.

3.11 Bij de hier aan de orde zijnde uitleg van de art. 7:663 en 7:664 BW dient voorts de omstandigheid te worden betrokken dat de werknemer die zowel voor als na de overgang van de onderneming verplicht deelneemt in hetzelfde bedrijfstakpensioenfonds, in die zin geen belang heeft bij het instellen van een vordering tot premiebetaling tegen de overdragende werkgever of de verkrijger, dat de verplichting van het pensioenfonds om aangesloten werknemers als zij aan de daartoe gestelde voorwaarden voldoen - pensioenuitkeringen te doen, bestaat onafhankelijk van het antwoord op de vraag in hoeverre door de werkgever de verschuldigde premie is voldaan. Als het pensioenfonds niet over een eigen recht zou beschikken om de verkrijger aan te spreken tot betaling van achterstallige premies, zou de nakoming van de - voor de dekkingsgraad van het totaal van de verplichtingen van het pensioenfonds belangrijke verplichting van de verkrijger om eventuele achterstallige premies te voldoen, dus onvoldoende zijn gewaarborgd.
Indirect kunnen daardoor ook de belangen van de werknemers zelf worden geschaad, namelijk in het geval het pensioenfonds wegens een te lage dekkingsgraad zou overgaan tot korting op de pensioenen (art. $134 \mathrm{Pw}$ ).

3.12 Tegen de achtergrond van hetgeen hiervoor in 3.10 en 3.11 is overwogen brengt een redelijke, en uit het oogpunt van een effectieve rechtsbescherming van de werknemers wenselijke, uitleg van de art. 7:663 en 7:664 BW mee dat bij overgang van een onderneming - behoudens de in art. 7:664 lid 1 BW genoemde uitzonderingen - in het geval de werknemer zowel voor als na de overgang van de onderneming verplicht deelneemt in hetzelfde bedrijfstakpensioenfonds, dit pensioenfonds een eigen recht verkrijgt tegen de verkrijger van de onderneming tot inning van eventueel achterstallige pensioenpremies. Het bedrijfstakpensioenfonds kan het vorderingsrecht dat het terzake kon uitoefenen jegens de overdragende werkgever, na overgang van de onderneming derhalve op dezelfde voet uitoefenen jegens de verkrijgende werkgever.' (curs. RvG, TS \& SH)

Uit de door ons gecursiveerde passages wordt ten eerste duidelijk dat het pensioenfonds een eigen vorderingsrecht op de werkgever heeft, dat is te onderscheiden van het recht van de werknemer om betaling van pensioenpremies aan het pensioenfonds af te dwingen. Ten tweede dat het recht jegens de werkgever om betaling aan het bedrijfspensioenfonds af te dwingen, (ook) een eigen recht is van de werknemer dat voortvloeit uit zijn arbeidscontract (dus: een recht op een betaling aan een derde). En ten derde dat het recht van het pensioenfonds ook uitgeoefend kan worden tegen een opvolgend werkgever indien sprake is geweest van overgang van onderneming.

Dit betekent dat de rechtspositie van de werknemer niet, althans niet wezenlijk, wordt aangetast wanneer de vordering van het pensioenfonds wordt gekort door middel van een WHOA-akkoord: de werknemer blijft onverminderd (a) jegens de onderneming gerechtigd tot enerzijds loon en anderzijds afdracht van pensioenpremies door de onderneming aan het pensioenfonds, en (b) jegens het pensioenfonds in de toekomst gerechtigd tot pensioen. Korting van het vorderingsrecht van het pensioenfonds vertaalt zich in beginsel niet in vermindering van het recht op pensioen van de werknemer jegens het pensioenfonds. De rechten van de werknemer jegens het pensioenfonds zijn in beginsel niet afhankelijk van de betaling van premies en bijdragen door zijn werkgever. ${ }^{11}$

De Hoge Raad zet het oordeel uit 2015 in de sleutel van de effectieve rechtsbescherming van de werknemers. Werknemersbescherming noopte tot het oordeel dat het bedrijfstakpensi-

11 Vgl. Parlementaire geschiedenis, Kamerstukken II 2005/06, 30413, nr. 3, p. 63. 


\section{Maandblad \\ Vermogensrecht}

oenfonds ${ }^{12}$ een eigen recht heeft (dat door de Hoge Raad wordt geduid als een 'vorderingsrecht') om betaling af te dwingen. De werknemer heeft waarschijnlijk geen direct belang zelf betaling af te dwingen, aangezien het recht van de werknemer jegens het pensioenfonds op uitkering van pensioen bestaat, ongeacht of afdracht van pensioenpremies door de werkgever heeft plaatsgevonden.

In zijn conclusie voor het arrest van 2015 heeft A-G Hartlief erop gewezen dat de deelnemers in een pensioenfonds gezamenlijk indirect door premieachterstanden worden geraakt, doordat het uitblijven van premiebetaling kan leiden tot onvoldoende dekkingsgraad en daarmee tot korting van de pensioenuitkeringen. ${ }^{13}$ De Hoge Raad heeft dit gezichtspunt vervolgens onderdeel gemaakt van zijn redenering, aan het slot van r.o. 3.11. Werknemersbescherming vormt derhalve mede de basis voor het oordeel dat het pensioenfonds een eigen aanspraak (vorderingsrecht) heeft. Wij merken hierbij op dat een vermindering van de dekkingsgraad van een pensioenfonds vele oorzaken naast elkaar kan hebben, en verder dat korting van pensioenrechten eerder pensioengerechtigde oud-werknemers zal treffen dan de bij de onderneming op dat moment werkzame werknemers.

Mogelijk van belang is dat het arrest is toegeschreven op het geval van overgang van onderneming ex art. 7:662 e.v. BW. De Hoge Raad oordeelt in dat kader dat de verplichtingen van de werkgever die voortvloeien uit verplichte deelneming in een bedrijfstakpensioenfonds moeten worden aangemerkt als verplichtingen die voortvloeien uit de arbeidsovereenkomst, waarvoor art. 7:663 BW voorschrijft dat de rechten en de verplichtingen bij overgang van onderneming behouden blijven. De Hoge Raad voegt daaraan toe dat dit strookt met het stelsel van de Pensioenwet.

Wat de vermogensrechtelijke verhoudingen betreft liggen de volgende uitgangspunten naar onze mening besloten in het arrest:

- De schuld van de onderneming, zijnde een (gemengd contractuele en wettelijke) verplichting tot afdracht en betaling van pensioenpremies, is een schuld aan het pensioenfonds. Hiermee correspondeert een eigen vorderingsrecht van het pensioenfonds. De crux van het arrest is dat een pensioenfonds zelf, door nakoming van zijn eigen vorderingsrecht te kunnen vorderen, de mogelijkheid moet hebben te bewerkstelligen dat pensioenpremies worden afge-

12 Het arrest betrof een bedrijfstakpensioenfonds als bedoeld in art. 1 Pensioenwet. Er bestaan ook andere typen pensioenfondsen, zoals een ondernemingspensioenfonds als bedoeld in art. 1 Pensioenwet, een beroepspensioenfonds als bedoeld in art. 1 Wet verplichte beroepspensioenregeling en een algemeen pensioenfonds als bedoeld in art. 1 Pensioenwet. Wij denken dat het type geen verschil uitmaakte in de procedure die resulteerde in het arrest uit 2015, en ook niet in het kader van een WHOA-procedure.

13 Concl. A-G Hartlief, ECLI:NL:PHR:2016:851, par. 4.5 bij HR 14 oktober 2016, ECLI:NL:HR:2016:2375. dragen, ook door de verkrijger na overgang van onderneming.

- De financiële schuld van de onderneming bestaat niet jegens de werknemer zelf, in die zin dat de pensioenpremies niet aan de werknemer zelf betaald hoeven te worden of zelfs mogen worden, aangezien betaling aan de werknemer zelf in strijd met het systeem van de Pensioenwet zou zijn.

- Wel rust op de onderneming jegens de werknemer een verbintenis waarvan de werknemer nakoming zou kunnen vorderen, maar dat is niet een verbintenis tot betaling van een geldsom aan de schuldeiser, maar verplichting tot betaling van een geldsom aan een (betrokken) derde (namelijk het pensioenfonds).

\subsection{Relevantie van het arrest voor de WHOA}

Het is de vraag of het arrest uit 2015 noopt tot de conclusie dat de vordering van een pensioenfonds op grond van art. 369 lid $4 \mathrm{Fw}$ buiten het toepassingsbereik van de WHOA-regeling valt. Het is op twee gronden mogelijk het gevalstype van dit arrest te onderscheiden van een WHOA-akkoord en de reikwijdte van het arrest uit 2015 niet te verruimen tot ook financiële herstructureringen onder de WHOA-regeling. Ten eerste rept het arrest uit 2015 van verplichtingen die voortvloeien uit de arbeidsovereenkomst in de zin van art. 7:663 $B W$, dat specifiek het kader van overgang van onderneming betreft; de strekking van de regeling van het WHOA-akkoord is significant anders dan bij overgang van onderneming. De Hoge Raad verwijst nadrukkelijk naar de memorie van toelichting bij de wet van 18 april 2002 (Wet overgang onderneming $)^{14}$ en het is dus niet vanzelfsprekend dat aan het arrest een ruimere strekking moet toekomen. Het is verdedigbaar, gezien de motivering die geënt is op art. 7:662 e.v. BW, dat dit niet het geval is. L.G. Verburg schrijft in zijn noot ${ }^{15}$ uitdrukkelijk dat het oordeel is gericht op de combinatie van en samenhang in de regels omtrent overgang van onderneming en die van de Wet verplichte deelneming in een bedrijfstakpensioenfonds 2000 (Wet Bpf 2000).

Ten tweede was de vraag in de procedure die leidde tot het arrest uit 2015, of het pensioenfonds zelf algehele betaling van achterstallige pensioenpremies kan vorderen, of in het geheel niet. In het kader van een WHOA-akkoord behoudt het pensioenfonds ten minste een deel van zijn vorderingsrecht, namelijk ten minste hetgeen in het hypothetische geval van liquidatie van de onderneming zou zijn verkregen. Het is bij een WHOA-akkoord dus niet een kwestie van alles of niets, zoals dat wel het geval was in het arrest uit 2015.

Hier staat tegenover dat de Hoge Raad in 2015 de werknemersbescherming centraal stelde en daarbij uitdrukkelijk de indirecte belangen vermeldde aan het slot van r.o. 3.11:

14 Wet van 18 april 2002, Stb. 2002, 215 (Wet overgang onderneming).

15 HR 14 oktober 2016, ECLI:NL:HR:2016:2375, Ondernemingsrecht $2017 / 19$. 


\section{Maandblad Vermogensrecht}

'Indirect kunnen daardoor ook de belangen van de werknemers zelf worden geschaad, namelijk in het geval het pensioenfonds wegens een te lage dekkingsgraad zou overgaan tot korting op de pensioenen.'

De Hoge Raad vervolgde dat 'een redelijke, en uit het oogpunt van een effectieve rechtsbescherming van de werknemers wenselijke, uitleg van de art. 7:663 en 7:664 BW' vergde dat het pensioenfonds een eigen vorderingsrecht zou hebben na overgang van de onderneming.

Van belang is dat het alleen gaat om reeds verschuldigd geworden, maar nog niet betaalde premieafdrachten. Met een WHOA-akkoord kan niet worden gekort op toekomstige pensioenpremiebetalingsverplichtingen.

\subsection{Een verdelingsvraagstuk}

Ook vermindering van (de omvang van) het eigen vorderingsrecht van het pensioenfonds door middel van een WHOA-akkoord kan indirecte gevolgen hebben voor de werknemer, zoals korting van pensioenrechten en pensioenaanspraken bij onvoldoende dekkingswaarde, meer in het bijzonder de toekomstige pensioenaanspraken. Het is dus de vraag of de Hoge Raad het belang van indirecte bescherming van werknemers in het kader van een WHOA-akkoord anders moet wegen dan in het kader van een overgang van onderneming. De gedachte achter een WHOA-akkoord is dat waarde voor de schuldeisers behouden kan blijven door een faillissement te voorkomen. Dit is ook in het voordeel van de pensioenuitvoerder en daarmee de werknemers. Als de vordering tot afdracht van (reeds verschuldigd geworden, maar onbetaald gebleven) premies niet kan worden meegenomen in een akkoord tot schuldenreductie, waardoor het risico groter is dat faillissement volgt, schaadt dit eerder het belang van de gezamenlijke en individuele werknemers dan dat dit hen beschermt; faillissement leidt niet alleen tot het verlies van hun baan, maar ook tot het risico dat de pensioenuitvoerder ten aanzien van reeds verschuldigde pensioenpremies minder zal ontvangen dan buiten faillissement. Hierin onderscheidt de situatie van een WHOA-akkoord zich van een overgang van onderneming. Gezien dit onderscheid is denkbaar dat het motief van werknemersbescherming in het arrest van 2015 anders wordt gewogen in het kader van een WHOA-akkoord en de uitleg van art. 369 lid 4 Fw.

Echter, het faillissement is niet het enige alternatief. Een WHOA-akkoord betreft de onderlinge verhouding van de verschillende klassen schuldeisers. Bij een WHOA-akkoord gaat het uiteindelijk om verdeling van de reorganisatiewaarde van een onderneming onder de verschillende klassen schuldeisers. Als de vordering van een pensioenfonds niet kan worden verlaagd, betekent dat in feite dat de verdeling van de reorgani- satiewaarde ${ }^{16}$ anders uitvalt, doordat de vordering van het pensioenfonds integraal in stand blijft. Het is dus een verdelingsvraagstuk, de verdeling van de waarde van de gereorganiseerde onderneming tussen de schuldeisers onderling.

Dat het een verdelingsvraagstuk is, geldt overigens eveneens voor de deelnemers in het pensioenfonds, want in geval van verlaging van de vordering van het pensioenfonds onder een WHOA-akkoord ontstaat een dekkingswaarderisico voor alle deelnemers, dat in geval van korting (of andere maatregelen als gevolg van het dekkingswaarderisico, zoals beperking van de indexering van uitkeringen) op de pensioenen uit een bedrijfstakpensioenfonds wordt verdeeld onder een groot aantal deelnemers. Het gaat dus niet alleen om allocatie van reorganisatiewaarde onder schuldeisers van de werkgever/schuldenaar, maar ook om spreiding van het dekkingswaarderisico onder de deelnemers in het pensioenfonds. Deze verdelingsvraagstukken bepalen mede of art. 369 lid 4 Fw zo uitgelegd wordt dat vorderingen van pensioenfondsen buiten de toepassing van een WHOA-akkoord blijven. Het is overigens maar de vraag of dit dekkingswaarderisico groot is als de vorderingen van het pensioenfonds in een WHOA-akkoord kunnen worden meegenomen. Toekomstige pensioenpremies worden immers niet geraakt door een WHOA-akkoord en zullen gewoon moeten worden betaald.

\subsection{Europees kader}

Men moet er steeds rekening mee houden dat de WHOA-procedure wordt gelegd langs de lat van Richtlijn (EU) 2019/1023 betreffende herstructurering en insolventie, van 20 juni 2019 (hierna: de Herstructureringsrichtlijn), die thans in alle lidstaten leidt tot invoering van een nieuw type insolventieprocedure, dat wordt geduid als een 'preventief schuldherstructureringsstelsel'. Het eerste ontwerp van de WHOA is ouder dan de Herstructureringsrichtlijn, maar uiteindelijk heeft de wetgever ervoor gekozen in de ontwerpregeling een aantal aanpassingen te maken, zodat de WHOA kan gelden als wet ter implementatie van de Herstructureringsrichtlijn. Strikt genomen is dit proces nog niet afgerond, want een wetsvoorstel met de benodigde aanpassingen moet nog aanhangig gemaakt worden. Toch lijkt onvermijdelijk dat de WHOA ook zonder die laatste aanpassingen moet worden beoordeeld op basis van de Herstructureringsrichtlijn; wij vinden het niet plausibel dat de WHOA nu nog kan ontsnappen aan toetsing door het Europees Hof van Justitie op de grond dat implementatie nog niet is afgerond. ${ }^{17} \mathrm{Wij}$ menen bovendien dat het, wanneer het op toetsing aan het Europese recht aankomt, niet uitmakt of een WHOA-procedure al dan niet openbaar is.

16 Ter voorkoming van misverstanden: er vindt na een WHOA-akkoord geen 'uitdeling' plaats; er zijn geen betalingen. Het verdelen van de reorganisatiewaarde betekent slechts dat de rechten van de verschillende schuldeisersgroepen, voor zover bestaande uit al dan niet opeisbare schulden, worden vastgesteld in het licht van de waarde van de onderneming na reorganisatie van de schulden.

17 Van den Sigtenhorst \& Jahan 2021, par. 3 en noot 12. 


\section{Maandblad \\ Vermogensrecht}

De Herstructureringsrichtlijn heeft EU-lidstaten veel ruimte geboden bij implementatie, maar vermeldt wel een mate van minimumbescherming van werknemers (zie vooral considerans par. 60-62). Heel expliciet is het slot van considerans par. 20:

'Een preventief herstructureringsstelsel dat is vastgesteld op grond van deze richtlijn mag geen invloed hebben op vorderingen en rechten tegen een schuldenaar die voortvloeien uit bedrijfspensioenregelingen indien deze vorderingen en rechten zijn opgebouwd tijdens een periode voorafgaand aan de herstructurering.'

Hieruit zou men de conclusie kunnen trekken dat de vorderingen van pensioenfondsen niet zouden kunnen worden getroffen door preventieve herstructureringsstelsels. Van belang is echter art. 1 lid 5 van de Herstructureringsrichtlijn, waarin is neergelegd dat de lidstaten kunnen bepalen dat bestaande of toekomstige vorderingen van huidige of voormalige werknemers worden uitgesloten van, of niet worden getroffen door preventieve herstructureringsstelsels. En verder art. 1 lid 6 van de Herstructureringsrichtlijn, waarin is bepaald dat de lidstaten ervoor zorgen dat preventieve herstructureringsstelsels opgebouwde rechten op bedrijfspensioenen onverlet laten. In art. 13 (inzake werknemers) zijn deze uitgangspunten verder uitgewerkt:

'De lidstaten zorgen ervoor dat het preventieve herstructureringsstelsel geen afbreuk doet aan de individuele en collectieve werknemersrechten uit hoofde van het uniaal en nationaal arbeidsrecht, zoals:

a. het recht op collectieve onderhandelingen en collectieve actie; en

b. het recht op informatie en raadpleging overeenkomstig Richtlijn 2002/14/EG en Richtlijn 2009/38/EG, met name:

i. informatie voor de werknemersvertegenwoordigers over de recente en waarschijnlijke evolutie van de activiteiten en de economische situatie van de onderneming of de vestiging, zodat zij opmerkingen over de situatie van de onderneming en wat betreft de noodzaak om herstructureringsmechanismen in overweging te nemen, aan de schuldenaar kunnen meedelen;

ii. informatie voor de werknemersvertegenwoordigers betreffende een eventuele preventieve herstructureringsprocedure die gevolgen kan hebben voor de werkgelegenheid, bijvoorbeeld voor het vermogen van werknemers om hun lonen en eventuele toekomstige betalingen, waaronder bedrijfspensioenen, terug te vorderen;

iii. informatie voor en raadpleging van de werknemersvertegenwoordigers over de herstructureringsplannen voordat zij overeenkomstig artikel 9 ter goedkeuring worden voorgelegd, of overeenkom- stig artikel 10 ter bevestiging door een rechterlijke of administratieve instantie;

c. de bij Richtlijnen 98/59/EG, 2001/23/EG en 2008/94/EG gegarandeerde rechten.' (curs. RvG, TS $\& \mathrm{SH})$

Uit de laatstgenoemde Richtlijn 2008/94/EG van 22 oktober 2008, betreffende de bescherming van de werknemers bij insolventie van de werkgever, is vooral art. 8 relevant:

'De lidstaten vergewissen zich ervan dat de nodige maatregelen worden getroffen om de belangen van de werknemers en die van de personen die de onderneming of vestiging van de werkgever op de datum van het intreden van de insolventie van de werkgever reeds hebben verlaten, te beschermen met betrekking tot hun verkregen rechten of hun rechten in wording op ouderdomsuitkeringen, met inbegrip van uitkeringen aan nagelaten betrekkingen, uit hoofde van voor een of meer bedrijfstakken geldende aanvullende stelsels van sociale voorzieningen welke bestaan naast de nationale wettelijke stelsels van sociale zekerheid.' (curs. RvG, TS \& SH)

In Nederland zijn de bedoelde belangen van werknemers beschermd doordat de pensioenen bij een separate pensioenuitvoerder zijn ondergebracht en het faillissement van de werkgever dus geen directe gevolgen heeft voor de pensioenrechten en pensioenaanspraken van een (oud-)werknemer. Het is plausibel dat het bij Richtlijn 2008/94/EG van 22 oktober 2008 vooral hierom te doen was.

Wanneer men art. 1 lid 6 van de Herstructureringsrichtlijn leest in het licht van art. 8 van Richtlijn 2008/94/EG achten wij dus goed verdedigbaar dat met art. 1 lid 6 van de Herstructureringsrichtlijn is beoogd de rechten van de werknemer op bedrijfspensioenen te beschermen, en niet vanzelfsprekend ook de rechten van een pensioenuitvoerder op de werkgever. De beperking in art. 1 lid 6 is in de considerans van de Herstructureringsrichtlijn echter niet uitdrukkelijk toegelicht. In ieder geval dwingt de Herstructureringsrichtlijn er niet toe vorderingen van pensioenfondsen uit te sluiten van het toepassingsbereik van preventieve schuldherstructureringsstelsels.

Wanneer een rechter zal moeten oordelen over de reikwijdte van art. 369 lid $4 \mathrm{Fw}$, zou het passend zijn als prejudiciële vragen worden gesteld aan het Europees Hof van Justitie over de uitleg en de reikwijdte van art. 1 lid 6 van de Herstructureringsrichtlijn in verband met een richtlijnconforme uitleg van art. 369 lid 4 Fw. Het is dan maar de vraag of het Hof de lijn van de Hoge Raad uit 2015 zal volgen, omdat ten aanzien van pensioenrechten en pensioenaanspraken nu juist geldt dat lidstaten uit hoofde van de andere richtlijn maatregelen moeten nemen die pensioenrechten en pensioenaanspraken van de werknemer beschermen tegen insolventie van de werkgever. In Nederland is in die bescherming voorzien door middel van 


\section{Maandblad Vermogensrecht}

zelfstandige pensioenfondsen waarvan het vermogen buiten de boedel van een gefailleerde werkgever valt. Het draait dan wat Nederland betreft nog slechts om de indirecte bescherming van werknemers, doordat bij korting van de vordering van het pensioenfonds tot betaling van achterstallige pensioenpremies de dekkingsgraad van dat pensioenfonds kan verslechteren en daarom de uitkeringen worden verlaagd of indexering van pensioenuitkeringen ten dele achterwege blijft. Of het Europees Hof van Justitie ook deze indirecte werknemersbescherming doorslaggevend zal achten, is onzeker. Het Hof zal ongetwijfeld meewegen dat het essentieel is gevonden om door middel van de Herstructureringsrichtlijn preventieve schuldherstructureringsstelsels in het leven te roepen in alle EU-lidstaten. Dan zal ook op Europees niveau de balans worden gezocht tussen (indirecte) werknemersbescherming en de ruimte voor het veiligstellen van de continuïteit van ondernemingen door middel van een onderhands schuldeisersakkoord. Dat is wezenlijk dezelfde discussie als die welke in Nederland met betrekking tot de WHOA wordt gevoerd, maar dan zonder meeweging van het arrest van de Hoge Raad uit 2015, maar met meeweging van Richtlijn 2008/94/EG van 22 oktober 2008, betreffende de bescherming van de werknemers bij insolventie van de werkgever, en de wijzen waarop deze richtlijn in de verschillende EU-lidstaten is geïmplementeerd.

\subsection{Conclusie A-G}

In de lopende prejudiciële procedure bij de Hoge Raad is de conclusie van A-G De Bock al genomen. ${ }^{18} \mathrm{Zij}$ geeft een uitvoerige beschrijving van de WHOA en de wetsgeschiedenis daarvan, met een focus op de uitzondering voor rechten van werknemers, en een uitputtend overzicht van de literatuur, alvorens een analyse te maken van het GOM-arrest van de Hoge Raad uit 2015. Zeer verkort weergegeven is haar analyse dat de Hoge Raad in zijn arrest uit 2015 de werknemersbescherming centraal heeft gesteld, waarbij zij ook wijst op de indirecte bescherming die verleend wordt tegen het risico van een dekkingstekort, met vermindering van de pensioenuitkeringen als mogelijk gevolg. Het arrest uit 2015 heeft volgens de A-G een algemene strekking en zij makt niet de hierboven weergegeven nuance dat de situatie bij een overgang van onderneming enigszins anders is dan bij een herstructurering van schulden na homologatie van een akkoord.

De A-G besteedt veel aandacht aan het gegeven dat de werknemer het recht heeft dat de werkgever pensioenpremies afdraagt. Dat recht vloeit voort uit de arbeidsovereenkomst en kennelijk is daarmee volgens haar gegeven dat de WHOA ook het recht (van de werknemer) op afdracht van pensioenpremies (aan het pensioenfonds) onverlet laat. Hierbij maken wij de kanttekening dat het vernieuwende element van het arrest van de Hoge Raad uit 2015 nu juist was dat het pensioenfonds een eigen recht op afdracht van pensioenpremies heeft. Met dit eigen recht op betaling correspondeert een schuld van de

18 Concl. A-G De Bock, ECLI:NL:PHR:2021:1152. werkgever jegens het pensioenfonds. Deze schuld is een zelfstandige schuld. Vermindering van de omvang ervan door middel van een WHOA-akkoord doet niets af aan het recht van de werknemer jegens het pensioenfonds op pensioenbetalingen. Ook de omvang van dit recht van de werknemer jegens het pensioenfonds wordt niet bepaald door de omvang van de vordering van het pensioenfonds op de werkgever.

Van belang is dat de A-G (in nr. 5.35 van haar conclusie) aansluiting zoekt bij een redenering van Lutjens. ${ }^{19}$ Lutjens stelt dat korting van de schuld aan het pensioenfonds geen zin heeft omdat de schuldenaar jegens de werknemer verplicht is en blijft om precies het bedrag van de achterstallige pensioenpremies af te dragen, weliswaar niet aan de werknemer zelf, maar aan het pensioenfonds. Dat kan naar onze mening ook anders worden gezien: het recht van de werknemer jegens de schuldenaar dat deze pensioenpremies betaalt aan het pensioenfonds, betreft niet noodzakelijkerwijs ook de omvang van de premiebetalingen. De schuldenaar blijft uit hoofde van de arbeidsovereenkomst jegens de werknemer verplicht pensioenpremies af te dragen aan het pensioenfonds, maar de omvang ervan staat daarmee niet noodzakelijkerwijs vast. Het recht van de werknemer jegens de werkgever/schuldenaar, dat de A-G brengt tot de conclusie dat het vorderingsrecht van het pensioenfonds niet verkort kan worden door een WHOA-akkoord, is dus van andere aard dan het recht op betaling van een geldsom. In essentie is het recht van de werknemer dat de werkgever pensioengelden afdraagt aan een externe uitvoerder en de pensioengelden dus niet onder zich houdt; zo bezien betreft het recht van de werknemer een verplichting om iets te doen (pensioengelden afdragen) en niet een vordering tot betaling (aan een derde) van een bepaalde geldsom met een bepaalde omvang. Het ene recht is het andere niet; een meer genuanceerde benadering, in het licht van het eigen vorderingsrecht van het pensioenfonds, bij de uitleg van art. 369 lid 4 Fw achten wij daarom mogelijk.

De A-G vermeldt aan het slot van haar conclusie (nr. 8.9) uitdrukkelijk dat zij zich kan voorstellen dat haar conclusie de effectiviteit van een WHOA-akkoord vermindert (zoals in par. 4 van deze bijdrage nog kort wordt uitgewerkt), maar dat het aan de wetgever is om daar iets aan te doen. Dat vinden wij spijtig. Nu de wet niet duidelijk tot een bepaalde uitleg dwingt, bestaat ruimte om een uitleg van de wet te kiezen die recht doet aan het doel van een WHOA. Er is in de wet en de wetsgeschiedenis niets dat noodzaakt tot de conclusie dat vorderingen van bedrijfstakpensioenfondsen uitgesloten zijn van de WHOA. Dan is een andere uitleg van art. 369 lid 4 Fw mogelijk, als rechtspolitieke overwegingen daartoe uitnodigen, bijvoorbeeld omdat een werknemer het meest gediend is met een akkoord dat ook achterstallige premieschulden kan betreffen.

19 E. Lutjens, noot bij de uitspraak van de Rb Amsterdam in deze procedure, 23 augustus 2021, ECLI:NL:RBAMS:2021:4475,in: Pensioen Jurisprudentie (PJ) 2021/133. 


\section{Maandblad \\ Vermogensrecht}

De A-G vermeldt de Europese dimensie van de WHOA-regeling slechts kort, namelijk daar waar zij stelt (in nr. 4.9) dat niet wordt toegekomen aan richtlijnconforme interpretatie waar de wetgever ruimte heeft benut die wordt geboden door de Herstructureringsrichtlijn. Deze biedt inderdaad ruimte om de rechten van werknemers uit te zonderen van een preventief herstructureringsstelsel, maar daarmee is nog niets gezegd over de marges van de geboden ruimte. Concreet is de vraag of pensioenfondsen kunnen meeliften op de rechten van werknemers, gezien de wijze waarop het pensioenstelsel in $\mathrm{Ne}$ derland door de wetgever en de Hoge Raad is vormgegeven. Het lijkt ons dat juist hier de vraag rijst hoeveel ruimte de Herstructureringsrichtlijn biedt om in een Nederlands kader de vorderingen van pensioenfondsen buiten beschouwing te laten. Richtlijnconforme interpretatie lijkt dus wel degelijk aan de orde, waarbij het Europees Hof van Justitie moet worden gevraagd om een oordeel over de marges van de in de Herstructureringsrichtlijn aan nationale wetgevers geboden ruimte om werknemersrechten uit te zonderen.

\subsection{Conclusie}

Het is moeilijk te voorspellen of een rechter in Nederland of het Europees Hof van Justitie tot het oordeel zal komen dat het vorderingsrecht van een pensioenfonds op grond van art. 369 lid 4 Fw binnen of buiten de reikwijdte van de uitsluiting van rechten van werknemers valt, en derhalve een verlaging binnen de kaders van een WHOA-akkoord wel of niet mogelijk is. Een uitleg conform de Herstructureringsrichtlijn lijkt onvermijdelijk, maar dan zal ook de met de richtlijn uit 2008 beoogde bescherming worden meegewogen. Op basis daarvan, en mede gezien het doel van de Herstructureringsrichtlijn, zijn wij van mening dat de vorderingen van een pensioenuitvoerder in Nederland niet onder de uitzondering van art. 369 lid $4 \mathrm{Fw}$ vallen. Daarbij zijn wij van mening dat de tekst van art. 369 lid $4 \mathrm{Fw}$ voldoende ruimte laat om deze nieuwe wettelijke bepaling beperkt uit te leggen.

\section{Een afkoelingsperiode}

Een belangrijk element van de WHOA-procedure is de mogelijkheid om een afkoelingsperiode te vragen op basis van art. 376 Fw. Tijdens een afkoelingsperiode kan elke bevoegdheid van een schuldeiser om zich te verhalen op goederen die tot het vermogen van de schuldenaar behoren, niet worden uitgeoefend (behoudens met machtiging van de rechtbank) en wordt de behandeling van een faillissementsaanvraag geschorst. De vraag is dan of een afkoelingsperiode ook kan zien op vorderingen van werknemers of oud-werknemers en op vorderingen van pensioenfondsen. Aangezien het gaat om verhaalsbevoegdheden, zijn alleen rechten die betaling van een geldsom behelzen relevant.

In een andere WHOA-procedure is door de rechtbank Amsterdam op grond van art. $376 \mathrm{Fw}$ een afkoelingsperiode van toepassing verklaard die ook betrekking lijkt te hebben op de rechten van oud-werknemers van de onderneming die een
WHOA-verklaring had gedeponeerd. ${ }^{20}$ Uit de uitspraak kunnen we niet afleiden of de gewezen werknemers hebben aangevoerd dat de afkoelingsperiode niet jegens hen zou gelden, gelet op art. 369 lid 4 Fw.

Op basis van de tekst van art. 369 lid 4 Fw zou kunnen worden geconcludeerd dat de afkoelingsperiode niet kan zien op de rechten van werknemers, aangezien art. 369 lid 4 Fw bepaalt dat het in de afdeling inzake de WHOA bepaalde niet van toepassing is.

Echter, op basis van de ratio van de afkoelingsperiode kan worden verdedigd dat de afkoelingsperiode van art. $376 \mathrm{Fw}$ ook ziet op rechten van werknemers, aangezien het - evenzeer als voor andere schuldeisers - onwenselijk zou zijn als een werknemer door faillissement aan te vragen een WHOA-traject zou kunnen frustreren. Dat geldt vermoedelijk ook voor oud-werknemers die betaling van een transitievergoeding vorderen, mits ook hun recht op volledige betaling maar voldoende gewaarborgd blijft gedurende de afkoelingsperiode. Gezien de ratio van een afkoelingsperiode onder de WHOA-regeling achten wij het denkbaar dat een afkoelingsperiode, die kan resulteren in schorsing van een door een schuldeiser ingediend verzoek tot faillietverklaring op grond van art. 376 lid 2 sub c Fw, ook ziet op schuldeisers die werknemer of oud-werknemer zijn.

In dit kader zijn verschillende leden van art. 6 van de Herstructureringsrichtlijn relevant:

'1. De lidstaten zorgen ervoor dat schuldenaren gebruik kunnen maken van een schorsing van individuele tenuitvoerleggingsmaatregelen om de onderhandelingen over een herstructureringsplan in het kader van een preventief herstructureringsstelsel te ondersteunen.

De lidstaten kunnen bepalen dat rechterlijke of administratieve instanties een schorsing van individuele tenuitvoerleggingsmaatregelen kunnen weigeren indien die schorsing niet nodig is of indien deze maatregel het beoogde doel van de eerste alinea niet zou verwezenlijken.'

'2. Onverminderd de leden 4 en 5 zorgen de lidstaten ervoor dat een schorsing van individuele tenuitvoerleggingsmaatregelen alle soorten vorderingen kan dekken, ook door zekerheden gedekte vorderingen en bevoorrechte vorderingen.'

' 5 . Lid 2 is niet van toepassing op vorderingen van werknemers.

In afwijking van de eerste alinea kunnen de lidstaten lid 2 op de vorderingen van werknemers toepassen indien en voor zover de lidstaten ervoor zorgen dat voor de betaling van die vorderingen in preventieve herstructureringsstel-

20 Rb. Amsterdam 15 januari 2021, ECLI:NL:RBAMS:2021:84. 


\section{Maandblad Vermogensrecht}

sels een vergelijkbaar beschermingsniveau wordt gewaarborgd.'

Dit art. 6 van de Herstructureringsrichtlijn geeft in lid 1 lidstaten de mogelijkheid om een maatregel te introduceren op grond waarvan individuele verhaalsacties geschorst kunnen worden, zoals in Nederland de afkoelingsperiode, maar geeft daarbij in lid 5 aan dat een dergelijke maatregel niet van toepassing kan zijn op rechten van werknemers, tenzij betaling van die rechten wordt gewaarborgd. De considerans van de Herstructureringsrichtlijn geeft geen verdere toelichting over de reikwijdte van deze bepaling, maar wij begrijpen die zo dat op grond van de richtlijn een dergelijke maatregel met schorsende werking niet voor rechten van werknemers en oud-werknemers kan gelden, tenzij de betaling gewaarborgd wordt. Wat deze waarborg precies moet behelzen, zou verder ingevuld moeten worden. Het is niet onmiddellijk duidelijk waartegen bescherming moet worden geboden aan bijvoorbeeld een oud-werknemer die recht heeft op een transitievergoeding; op de keper beschouwd gaat het om de gevolgen van opschorting van de verhaalsmogelijkheden, zonder dat zeker is dat de onderneming uiteindelijk levensvatbaar kan worden gemaakt door middel van een WHOA-akkoord.

Maar ook wat de afkoelingsperiode betreft rijst de vraag of het een pensioenfonds vrijstaat individuele verhaalsacties te nemen. Dat is voor ons een vraag, zelfs indien wordt geoordeeld dat de uitzondering voor rechten van werknemers in art. 369 lid $4 \mathrm{Fw}$ ook voor vorderingen van het pensioenfonds geldt. Het pensioenfonds is immers een ander type persoon dan de werknemer. Het is niet per se evident dat een pensioenfonds onverkort moet kunnen doen wat een werknemer kan. Waar het individuele verhaalsacties betreft, is er wel enige reden om onderscheid te maken tussen de werknemer zelf en het pensioenfonds. Waar beslag en eventueel een faillissementsaanvraag door een werknemer met betrekking tot hetgeen aan de werknemer is verschuldigd nog te billijken vallen, is niet evident dat het pensioenfonds ook daartoe in staat moet worden gesteld. Een pensioenfonds is beter in staat te wachten op zijn geld dan een werknemer. Deze nuance kan best worden gemaakt bij de uitleg van zowel art. 369 lid $4 \mathrm{Fw}$ als art. $376 \mathrm{Fw}$.

Wetstechnisch zijn verschillende lijnen denkbaar om binnen het kader van de wet te komen tot de conclusie dat de afkoelingsperiode ook de vordering van een pensioenfonds treft, zelfs indien wenselijk wordt geacht dat die vordering niet in het WHOA-akkoord kan worden meegenomen. Eén lijn kan zijn dat geoordeeld wordt dat vorderingen van pensioenfondsen niet vallen onder de uitzondering van art. 369 lid 4 Fw, maar dat deze bepaling wel analogisch wordt toegepast op die vorderingen ten behoeve van (indirecte) werkgeversbescherming. Dan geldt de WHOA-regeling wel voor vorderingen van pensioenfondsen (met inbegrip van de afkoelingsperiode), maar zou analogische toepassing van art. 369 lid $4 \mathrm{Fw}$ ertoe kunnen leiden dat vorderingen van pensioenfondsen niet kunnen worden gekort door middel van een WHOA-akkoord. De andere mogelijke lijn is dat vorderingen van pensioenfondsen wel gelijk worden gesteld aan rechten van werknemers, zodat art. 369 lid $4 \mathrm{Fw}$ erin resulteert dat de WHOA-regeling niet direct van toepassing is op vorderingen van pensioenfondsen, maar dat de regel van art. $376 \mathrm{Fw}$ toch (analogisch) wordt toegepast op vorderingen van pensioenfondsen. In beide wetstechnische benaderingen is het eindresultaat dat een afkoelingsperiode ook vorderingen van pensioenfondsen treft. Dat resultaat lijkt ons wenselijk, want het succes van de WHOA-regeling als instrument om een onderneming in financiële moeilijkheden te laten overleven, is mede afhankelijk van de mogelijkheid een afkoelingsperiode af te kondigen.

\section{Conclusie}

Een onderneming in financiële moeilijkheden, die ook achterstallige pensioenpremies verschuldigd is aan een pensioenfonds, verkeert thans nog in onzekerheid of die schulden ook onderdeel kunnen worden van een WHOA-akkoord. Er moet eerst duidelijkheid komen of de bepaling in art. 369 lid 4 Fw, die rechten van werknemers uitzondert van het toepassingsbereik van de WHOA-regeling, ook van toepassing is op rechten van pensioenfondsen op de onderneming. Zolang dat niet duidelijk is, is onzeker of het pensioenfonds als schuldeiser betrokken kan worden in een WHOA-procedure, zodat het kan stemmen over vermindering van hetgeen de onderneming aan het pensioenfonds verschuldigd is. Bij een tegenstem kan het WHOA-akkoord toch, door middel van homologatie door de rechtbank, verbindend worden verklaard, ook voor de tegenstemmende schuldeisers, waaronder dan ook het pensioenfonds.

Het valt te hopen dat de Hoge Raad voldoende duidelijkheid op dit punt gaat bieden. Naar onze inschatting kan de Hoge Raad dat beter niet zomaar beslissen, aangezien er een Europese dimensie besloten ligt in het vraagstuk. Hier komt bij dat van een WHOA-beslissing van de rechtbank geen hoger beroep mogelijk is onder de WHOA-regeling. De reikwijdte van de uitzondering voor rechten van werknemers zou daarom moeten worden voorgelegd aan het Europees Hof van Justitie. ${ }^{21}$ Het communautaire recht voorziet in een versnelde rechtsgang. ${ }^{22}$ In het verleden is insolventierecht genoemd als een rechtsgebied waarin een versnelde rechtsgang toelaatbaar is.

Voor de overlevingskansen van een onderneming is het uiteraard beter als ook de vordering van een pensioenfonds kan worden meegenomen in het WHOA-akkoord, want dan kan een groter deel van de reorganisatiewaarde worden gealloceerd aan andere groepen schuldeisers. Dat vergroot de kans dat die andere groepen instemmen met een akkoord. Bovendien wordt voorkomen dat in sommige gevallen überhaupt geen

21 Vgl. HvJ EU 6 oktober 2021, ECLI:EU:C:2021:799 (Consortio Italian Management/Rete Ferroviaria Italiana): de nationale hoogste rechter moet motiveren waarom hij geen prejudiciële vragen stelt als er onduidelijkheid bestaat over Europees recht.

22 Art. 23bis van het Statuut van het HvJ EU. 


\section{Maandblad}

mogelijkheid bestaat om een WHOA-akkoord aan te bieden dat voor homologatie in aanmerking komt, namelijk in de gevallen waarin door de hoogte van de vordering van het pensioenfonds aan de overige schuldeisers niet ten minste kan worden geboden wat hun in faillissement zou toekomen. De effectiviteit van de WHOA-regeling als preventief herstructureringsinstrument wordt dus vergroot wanneer vorderingen van pensioenfondsen mee kunnen worden genomen in een WHOA-akkoord.

Ten slotte is ook van belang of een afkoelingsperiode kan voorkomen dat een pensioenfonds verhaalsacties kan nemen of faillissement kan aanvragen, terwijl de onderneming bezig is met de voorbereiding van een WHOA-akkoord. Het spreekt vanzelf dat het van belang is dat een pensioenfonds de voorbereiding niet kan doorkruisen, en een pensioenfonds verdient niet hetzelfde beschermingsniveau in dit opzicht als een werknemer zelf. Zelfs indien de vordering van een pensioenfonds wordt begrepen onder het begrip 'rechten van een werknemer', zien wij mogelijkheden en gronden om de regeling van een afkoelingsperiode daarop van toepassing te laten zijn. 